\title{
Gliclazide and bedtime insulin are more efficient than insulin alone for type 2 diabetic patients with sulfonylurea secondary failure
}

A.C.S. Chazan and M.B. Gomes
Unidade de Diabetes, Departamento de Medicina, Hospital da Universidade Estadual do Rio de Janeiro, Rio de Janeiro, RJ, Brasil

\section{Correspondence}

A.C.S. Chazan

Rua do Catete, 311/812

22220-001 Rio de Janeiro, RJ Brasil

E-mail: chazan@ altavista.net

Received December 30, 1998 Accepted August 14, 2000

\section{Abstract}

To determine the effects of combined therapy of gliclazide and bedtime insulin on glycemic control and C-peptide secretion, we studied 25 patients with type 2 diabetes and sulfonylurea secondary failure, aged $56.8 \pm 8.3$ years, with a duration of diabetes of $10.6 \pm 6.6$ years, fasting plasma glucose of $277.3 \pm 64.6 \mathrm{mg} / \mathrm{dl}$ and a body mass index of $27.4 \pm 4.8 \mathrm{~kg} / \mathrm{m}^{2}$. Patients were submitted to three therapeutic regimens lasting 2 months each: $320 \mathrm{mg}$ gliclazide (phase 1), $320 \mathrm{mg}$ gliclazide and bedtime NPH insulin (phase 2), and insulin (phase 3 ). At the end of each period, glycemic and C-peptide curves in response to a mixed meal were determined. During combined therapy, there was a decrease in all glycemic curve values $(\mathrm{P}<0.01)$. Twelve patients (48\%) reached fasting plasma glucose $<140 \mathrm{mg} / \mathrm{dl}$ with a significant weight gain of $64.8 \mathrm{~kg}(43.1-98.8)$ vs $66.7 \mathrm{~kg}(42.8-101.4)(\mathrm{P}<0.05)$, with no increase in C-peptide secretion or decrease in HbA1. CPeptide glucose score (C-peptide/glucose x 100) increased from 0.9 $(0.2-2.1)$ to $1.3(0.2-4.7)$ during combined therapy $(\mathrm{P}<0.01)$. Despite a 50\% increase in insulin doses in phase 3 (12 U (9-30) vs $18 \mathrm{U}$ (11$60)$; $\mathrm{P}<0.01$ ) only 3 patients who responded to combined therapy maintained fasting plasma glucose $<140 \mathrm{mg} / \mathrm{dl}(\mathrm{P}<0.02)$. A tendency to a higher absolute increase in C-peptide $(0.99(0.15-2.5)$ vs $0.6(0$ 2.15); $\mathrm{P}=0.08)$ and $\mathrm{C}$-peptide incremental area (2.47 (0.22-6.2) vs 1.2 $(0-3.35) ; \mathrm{P}=0.07)$ was observed among responders. We conclude that combined therapy resulted in a better glucose response to a mixed meal than insulin alone and should be tried in type 2 diabetic patients before starting insulin monotherapy, despite difficulties in predicting the response.

\section{Introduction}

Sulfonylurea (SU) secondary failure is the lack of continued response to SU despite initial successful treatment. After excluding those patients who did not adhere to their diets, those given inadequate dosage, those
Key words

- Diabetes mellitus type 2

- C-Peptide

- Secondary failure with metabolic stress (1), or those who were, in fact, insulin dependent (2), it seems that secondary failure is determined by the disease itself (3).

The first combined therapy for diabetes type 2 was insulin plus SU (4). Its routine use in clinical practice is justified by extensive 
experimental evidence that at the time of secondary failure to $\mathrm{SU}$, evening insulin plus daytime oral agents are more effective than a single injection of insulin, and just as effective as a more complex multiple injection regimen without an oral agent $(5,6)$. Several investigators have used C-peptide measurements in order to identify non-insulin dependency (7) or best responders to combined therapy $(8,9)$, but there is no universal consensus about the method of stimulus application to be used to assess residual betacell function in type 2 diabetic patients.

The objective of the present study was to evaluate the pancreatic reserve on the basis of the C-peptide response to a mixed meal in order to identify the good responders to combined therapy among a group of 25 secondary failure type 2 diabetic patients.

\section{Patients and Methods}

Twenty-five outpatients with diabetes type 2 (18 female, 7 male), attending the Diabetes Clinic of the Rio de Janeiro State University, Rio de Janeiro, RJ, Brazil, who satisfied the National Diabetes Data Group criteria (10), aged $56.8 \pm 8.3$ years, with known diabetes duration of $10.6 \pm 6.6$ years, fasting plasma glucose (FPG) of $277.3 \pm$ $64.6 \mathrm{mg} / \mathrm{dl}$ and a body mass index (BMI) of $27.4 \pm 4.8 \mathrm{~kg} / \mathrm{m}^{2}$, were invited to participate in this study after its approval by the Medical Ethics Committee of the University.

Patients were selected if they had SU secondary failure, defined as at least two FPG values $>180 \mathrm{mg} / \mathrm{dl}$ during a run-in period of two months of maximum dosage of SU (20 mg glibenclamide, $\mathrm{N}=15 ; 320 \mathrm{mg}$ gliclazide, $\mathrm{N}=7 ; 500 \mathrm{mg}$ chlorpropamide, $\mathrm{N}$ $=2$, and $30 \mathrm{mg}$ glipizide, $\mathrm{N}=1$ ), excluding clinical illness and dietetic flaws (3). On that occasion dietary orientation was optimized and instructions in self-monitoring of the urine glucose test were given.

The exclusion criteria were creatinine clearance below $70 \mathrm{ml} \mathrm{min}{ }^{-1} 1.73 \mathrm{~m}^{-2}$, the presence of any ophthalmopathy which prevented insulin self-application, or symptoms of marked hyperglycemia (polyuria, polydipsia, weight loss).

The study consisted of three phases, each lasting two months: gliclazide (320 mg) (phase 1), gliclazide (320 mg) and bedtime NPH insulin (phase 2), and insulin as monotherapy (phase 3 ).

Before entering the study, a washout period of 15 days was applied to all patients, except those who were using gliclazide $(\mathrm{N}=$ 7). For those using $320 \mathrm{mg} /$ day gliclazide, the run-in period corresponded to phase 1 .

At the end of phase 1, the criterion for eligibility for phase 2 was persistence of secondary failure to respond to gliclazide as described above.

Patients were seen at 2-week intervals, when the presence of hypoglycemia symptoms and the results of the urine tests for glucose were checked.

During phase 2, the initial insulin dose was 6-10 U per night, varying according to patient weight ( $6 \mathrm{U}$ for lean patients, $8 \mathrm{U}$ for overweight patients and $10 \mathrm{U}$ for obese patients). The insulin doses were adjusted to obtain FPG $<140 \mathrm{mg} / \mathrm{dl}$.

Gliclazide was discontinued at the beginning of phase 3 and insulin doses were adjusted to obtain FPG $<140 \mathrm{mg} / \mathrm{dl}$. Patients with FPG $<140 \mathrm{mg} / \mathrm{dl}$ at the end of phases 2 and 3 were considered to be responders to combined therapy or to insulin as monotherapy (11).

At the end of each phase, glycemia and C-peptide curves in response to a mixed meal, $\mathrm{HbA} 1$, body weight and systolic blood pressure were studied. Subjects arrived at the hospital after a 10-h overnight fast. A standard mixed meal consisting of $200 \mathrm{ml}$ of cow's milk ( $2 \%$ of fat) and 7 crackers was used as a stimulus (test meal), corresponding to a total of $317 \mathrm{kcal}(55.7 \%$ carbohydrates, $14.8 \%$ proteins and $29.5 \%$ lipids). This meal is similar to our patients' typical breakfast and corresponds to $20 \%$ of their daily calorie 
intake. Blood sampling was performed before the ingestion of the meal and at 30,60 and $120 \mathrm{~min}$ after ingestion. In our previous observations this test meal was able to stimulate the C-peptide response in a group of nondiabetic controls (12).

Glucose was measured by an automated enzymatic colorimetric method (Cobas Mira Roche, Reutkroz, Switzerland). C-Peptide was measured by radioimmunoassay (Diagnostic Product Corporation, Los Angeles, CA, USA; sensitivity: $0.05 \mathrm{ng} / \mathrm{ml}$ ), after the removal of insulin antibody by precipitation with polyethylene glycol. Serum was stored at $-20^{\circ} \mathrm{C}$ for a maximum period of 3 months. The intra- and interassay coefficients of variation were 7 and $9.1 \%$, respectively. $\mathrm{HbA} 1$ was determined by ion exchange chromatography (Boehringer-Mannheim, Mannheim, Germany), with a reference range of 4.5-8\%.

The following parameters of the glucose and C-peptide curves were analyzed: 1) basal value $(\mathrm{BV}) ; 2)$ peak value $(\mathrm{PV})$ : the highest value above the basal one after the standard meal stimulation. In patients who showed no increase after stimulation, PV was considered to be equal to $\mathrm{BV} ; 3$ ) absolute increase: absolute difference between $\mathrm{PV}$ and $\mathrm{BV}$; 4) percent increase (PI): percent difference between $\mathrm{PV}$ and $\mathrm{BV}$; 5) incremental area under the curve (IAUC): area below the curve and above baseline; 6) total area under the curve (TAUC): area below the curve. IAUC and TAUC were obtained by a numerical integral calculation.

The beta-cell sensitivity to glucose stimulation was evaluated for each patient by the following index, calculated as (C-peptide/ glucose ratio) x 100 (13).

\section{Statistical analysis}

The three treatments were compared by the Friedman test followed by the Wilcoxon signed rank test with Bonferroni correction. The data for responders and nonresponders to combined therapy were compared by the Mann-Whitney U-test. Spearman's rank correlation was used to test the degree of association between the variables studied. Patients who showed no increment were excluded from this analysis. These analyses were performed using the statistical program Statistica, version 5.0, for Windows. The results are expressed as median and range. A two-sided $\mathrm{P}$ value less than 0.05 was considered to be significant.

\section{Results}

During combined therapy 12 patients (48\%) reached FPG $<140 \mathrm{mg} / \mathrm{dl}$. No increment in C-peptide secretion (Table 1) or decrease in $\mathrm{HbA} 1$ (Table 2) was noted. The C-peptide glucose score increased $(0.9$ (0.22.1) vs 1.3 (0.2-4.7); $\mathrm{P}=0.008)$ during combined therapy with no difference between phases 1 and 3. Combined therapy resulted in weight gain (64.8 $\mathrm{kg}$ (43.1-98.8) vs 66.7 $\mathrm{kg}$ (42.8-101.4); $\mathrm{P}=0.005)$, with no change in systolic blood pressure (Table 3). An increase in insulin dose was observed during phase 3 in comparison to phase $2(0.19 \mathrm{U} / \mathrm{kg}$ (0.13-0.39) vs $0.27 \mathrm{U} / \mathrm{kg}(0.15-0.77) ; \mathrm{P}=$ 0.001) (Table 3). Despite this increase in insulin doses in phase 3 , only three patients among the responders to combined therapy maintained FPG $<140 \mathrm{mg} / \mathrm{dl}(\mathrm{P}<0.02)$. Mild hypoglycemia (self-reported), not confirmed by the capillary glucose test, was recorded in 7 patients (28\%) in phase 2 and in 5 patients $(20 \%)$ in phase 3.

All the glucose curve parameters analyzed were significantly different among the three phases (Table 2). A decrease in glucose PV between phase 1 and phase 2 (290 $\mathrm{mg} / \mathrm{dl}(183-535)$ vs $214 \mathrm{mg} / \mathrm{dl}(150-418) ; \mathrm{P}=$ $0.0006)$ and between phase 2 and phase 3 (214 mg/dl (150-448) vs $281.5 \mathrm{mg} / \mathrm{dl}$ (147$479) ; \mathrm{P}=0.0016)$ was observed. An absolute increase in glucose was found in phase 3 in comparison to phase $1(90 \mathrm{mg} / \mathrm{dl}(0-153.5)$ vs $54.5 \mathrm{mg} / \mathrm{dl}(0-120) ; \mathrm{P}=0.0001)$ and in 
phase 2 in comparison to phase $1(68.5 \mathrm{mg} /$ $\mathrm{dl}(21-166)$ vs $54.5 \mathrm{mg} / \mathrm{dl}(0-120) ; \mathrm{P}=0.009)$. An increase in glucose PI was found in phase 2 in comparison to phase $1(47.01 \%(12.8-$ 174.34) vs $24.01 \%(0-50.77) ; \mathrm{P}=0.0001)$ and in phase 3 in comparison to phase 1 (40.45\% (0-171.76) vs 24.01\% (0-50.77); P $=0.0006)$. In all three phases, a correlation between glucose PV and glucose $\mathrm{BV}(\mathrm{rS}=$ $0.86, \mathrm{P}<0.01 ; \mathrm{rS}=0.72, \mathrm{P}<0.01 ; \mathrm{rS}=0.78$, $\mathrm{P}<0.01$, respectively) and between glucose TAUC and glucose $\mathrm{BV}(\mathrm{rS}=0.94, \mathrm{P}<0.01$; $\mathrm{rS}=0.88, \mathrm{P}<0.01 ; \mathrm{rS}=0.88, \mathrm{P}<0.01$, respectively) was observed. C-peptide $\mathrm{PV}$ was correlated with the basal C-peptide in all three phases $(\mathrm{rS}=0.83, \mathrm{P}<0.01$;

Table 1 - C-Peptide response to a test meal and C-peptide/glucose score at the end of each treatment phase.

Data are reported as median (minimum-maximum). A significant difference in C-peptide/glucose score was found between the 3 phases (Friedman test), with a difference between phase 2 and phase 1 ( $* P=0.008$, Wilcoxon test). IAUC and TAUC: Incremental and total area under the curve.

\begin{tabular}{lllll}
\hline Variable & \multicolumn{1}{c}{$\begin{array}{c}\text { Phase } 1 \\
\text { (gliclazide) }\end{array}$} & \multicolumn{1}{c}{$\begin{array}{c}\text { Phase 2 } \\
\text { (gliclazide + insulin) }\end{array}$} & \multicolumn{1}{c}{$\begin{array}{c}\text { Phase 3 } \\
\text { (insulin) }\end{array}$} & P \\
\hline Basal value (ng/ml) & $2.05(0.4-3.8)$ & $1.9(0.6-4.85)$ & $1.2(0.15-4.95)$ & 0.61 \\
$30 \mathrm{~min}(\mathrm{ng} / \mathrm{ml})$ & $2.5(0.31-4.15)$ & $2.1(0.4-8.2)$ & $1.5(0.3-6.2)$ & 0.35 \\
$60 \mathrm{~min}(\mathrm{ng} / \mathrm{ml})$ & $2.8(0.34-5.3)$ & $2.3(0.3-4.6)$ & $1.5(0.2-5.3)$ & 0.26 \\
$120 \mathrm{~min}(\mathrm{ng} / \mathrm{ml})$ & $2.4(0.47-5.9)$ & $2.1(0.5-6.1)$ & $1.75(0.4-5.7)$ & 0.06 \\
Peak value $(\mathrm{ng} / \mathrm{ml})$ & $2.9(0.6-5.9)$ & $2.5(0.7-8.2)$ & $2.5(0.6-6.2)$ & 0.26 \\
Absolute increase $(\mathrm{ng} / \mathrm{ml})$ & $0.7(0-2.5)$ & $0.5(0-3.35)$ & $0.36(0-3.07)$ & 0.14 \\
Percent increase $(\%)$ & $39.47(0-110.25)$ & $28.88(0-87.09)$ & $25.25(0-900)$ & 0.20 \\
IAUC (ng ml-1 $\left.\mathrm{min}^{-1}\right)$ & $52.50(0-186.0)$ & $31.50(0-156.75)$ & $35.25(0-206.1)$ & 0.22 \\
TAUC $\left(\mathrm{ng} \mathrm{ml}{ }^{-1} \mathrm{~min}^{-1}\right)$ & $311.25(50.4-581.7)$ & $256.80(56.25-648.75)$ & $203.25(54.75-669.75)$ & 0.36 \\
C-Peptide/glucose score & $0.9(0.2-2.1)$ & $1.3 *(0.2-4.7)$ & $0.7(0.1-2.3)$ & 0.02
\end{tabular}

Table 2 - Plasma glucose response to a test meal and $\mathrm{HbAl}$ at the end of each treatment phase.

Data are reported as median (minimum-maximum). HbAl: Glycated hemoglobin, IAUC and TAUC: incremental and total area under the curve. ${ }^{*} P<0.01$, phase 1 vs 2 and phase 2 vs 3 (Wilcoxon test); ${ }^{+} P<0.01$, phase 1 vs 2 and phase 1 vs 3 (Wilcoxon test). A significant difference in glycemic curve parameters was found between the 3 phases (Friedman test).

\begin{tabular}{|c|c|c|c|c|}
\hline Variable & $\begin{array}{l}\text { Phase } 1 \\
\text { (gliclazide) }\end{array}$ & $\begin{array}{c}\text { Phase } 2 \\
\text { (gliclazide }+ \text { insulin) }\end{array}$ & $\begin{array}{l}\text { Phase } 3 \\
\text { (insulin) }\end{array}$ & $P$ \\
\hline Basal value (mg/dl) & $242.5(138.5-449.5)$ & $155(86-384)$ & $189(85-358)$ & 0.0019 \\
\hline $30 \mathrm{~min}(\mathrm{mg} / \mathrm{dl})$ & $250(101-440)$ & $148(99-424)$ & $215(93-402)$ & 0.0032 \\
\hline $60 \mathrm{~min}(\mathrm{mg} / \mathrm{dl})$ & $266(81-527)$ & 190 (122-448) & 243 (126-479) & 0.0028 \\
\hline $120 \mathrm{~min}(\mathrm{mg} / \mathrm{dl})$ & $280(70-535)$ & $214(150-418)$ & $276(124-440)$ & 0.0007 \\
\hline Peak value (mg/dl) & $290(183-535)$ & $214 *(150-448)$ & $281.50(147-479)$ & 0.0001 \\
\hline Absolute increase (mg/dl) & $54.5^{+}(0-120)$ & $68.5(21-166.5)$ & $90(0-153.5)$ & 0.0003 \\
\hline Percent increase (\%) & $24.01^{+}(0-50.77)$ & 47.01 (12.8-174.34) & $40.45(0-171.76)$ & 0.0002 \\
\hline IAUC $\left(x 10^{3}\right)\left(\mathrm{mg} \mathrm{dl}^{-1} \mathrm{~min}^{-1}\right)$ & $3.77(0-9.15)$ & $4.73(2.0-10.16)$ & $6.17(0-11.35)$ & 0.0001 \\
\hline TAUC $\left(\times 10^{4}\right)\left(\mathrm{mg} \mathrm{dl}^{-1} \mathrm{~min}^{-1}\right)$ & $3.05(1.18-5.97)$ & $2.14(1.46-5.12)$ & $2.78(1.63-5.2)$ & 0.0024 \\
\hline $\mathrm{HbAl}(\%)$ & $9.2(6.8-13.8)$ & $8.8(5-12.5)$ & $8.8(5.5-13.4)$ & 0.43 \\
\hline
\end{tabular}


$\mathrm{rS}=0.85, \mathrm{P}<0.01 ; \mathrm{rS}=0.87, \mathrm{P}<0.01$, respectively).

The glucose BV, the C-peptide BV, and the C-peptide/glucose score in phase $1 \mathrm{did}$ not identify the patients who would respond or not to combined therapy (Table 4).

Age at diagnosis, diabetes duration and BMI did not differ between responders and nonresponders. Responders were older than nonresponders ( 63.5 years (39-72) vs 55 years (44-60); $\mathrm{P}<0.035)$. Responders tended to show higher values of the variables that express C-peptide increment after the meal: $\mathrm{C}$ peptide absolute increase $(0.99 \mathrm{ng} / \mathrm{ml}(1.15$ 2.5) vs $0.6 \mathrm{ng} / \mathrm{ml}(0-2.15) ; \mathrm{P}=0.08)$ and $\mathrm{C}$ peptide IAUC $\left(2.47 \mathrm{ng} \mathrm{ml}^{-1} \mathrm{~min}^{-1}(0.22-6.2)\right.$ vs $\left.1.2 \mathrm{ng} \mathrm{ml}^{-1} \mathrm{~min}^{-1}(0-3.35) ; \mathrm{P}=0.07\right)$ (Table 4).

Table 3 - Patient data during each treatment phase.

Data are reported as median (minimum-maximum). BMI: Body mass index, SBP: systolic blood pressure, DBP: diastolic blood pressure. ${ }^{*} \mathrm{P}=0.005$ vs phase 1 (Wilcoxon test). A significant difference in body weight and BMI was found between the 3 phases (Friedman test) and in insulin dose (phase 2 vs phase 3; Wilcoxon test).

\begin{tabular}{lllll}
\hline Clinical data & \multicolumn{1}{c}{$\begin{array}{c}\text { Phase 1 } \\
\text { (gliclazide) }\end{array}$} & $\begin{array}{c}\text { Phase 2 } \\
\text { (gliclazide + insulin) }\end{array}$ & \multicolumn{1}{c}{$\begin{array}{c}\text { Phase 3 } \\
\text { (insulin) }\end{array}$} & P \\
\hline Body weight $(\mathrm{kg})$ & $64.8(43.1-98.8)$ & $66.7^{*}(42.8-101.4)$ & $65.8(42.7-104)$ & 0.016 \\
BMI $\left(\mathrm{kg} / \mathrm{m}^{2}\right)$ & $26.19(18.17-37.41)$ & $26.78^{*}(18.05-37.51)$ & $26.49(18-37.74)$ & 0.016 \\
SBP $(\mathrm{mmHg})$ & $150(110-180)$ & $140(110-180)$ & $140(110-170)$ & 0.08 \\
DBP $(\mathrm{mmHg})$ & $80(70-100)$ & $80(60-100)$ & $80(60-90)$ & 0.53 \\
Insulin dose $(\mathrm{U})$ & - & $12(9-30)$ & $18^{*}(11-60)$ & 0.001 \\
Insulin dose $(\mathrm{U} / \mathrm{kg})$ & - & $0.19(0.13-0.39)$ & $0.27^{*}(0.15-0.77)$ & 0.001
\end{tabular}

Table 4 - Glucose and C-peptide responses to a test meal at the end of phase 1 (gliclazide) by responders and nonresponders to combined therapy.

Data are reported as median (minimum-maximum). A significant difference in percent increase of glucose was found in responders (Mann-Whitney test). IAUC and TAUC: Incremental and total area under the curve.

\begin{tabular}{|c|c|c|c|c|c|c|c|}
\hline & \multicolumn{3}{|c|}{ Glucose curve } & & \multicolumn{3}{|c|}{ C-peptide curve } \\
\hline & $\begin{array}{c}\text { Responders } \\
\mathrm{N}=12(48 \%)\end{array}$ & $\begin{array}{c}\text { Nonresponders } \\
N=13(52 \%)\end{array}$ & $P$ & & $\begin{array}{l}\text { Responders } \\
\mathrm{N}=12(48 \%)\end{array}$ & $\begin{array}{l}\text { Nonresponders } \\
\mathrm{N}=13(52 \%)\end{array}$ & $P$ \\
\hline $\begin{array}{l}\text { Basal value } \\
\text { (mg/dl) }\end{array}$ & $\begin{array}{l}237.25 \\
(138.5-282.5)\end{array}$ & $\begin{array}{l}254 \\
(160.5-449.5)\end{array}$ & 0.36 & $\begin{array}{l}\text { Basal value } \\
(\mathrm{ng} / \mathrm{ml})\end{array}$ & $\begin{array}{l}2.22 \\
(0.52-3.53)\end{array}$ & $\begin{array}{l}1.85 \\
(0.4-3.8)\end{array}$ & 0.53 \\
\hline $\begin{array}{l}\text { Peak value } \\
\text { (mg/dl) }\end{array}$ & $\begin{array}{l}285.5 \\
(183-377)\end{array}$ & $\begin{array}{l}290 \\
(205-535)\end{array}$ & 0.93 & $\begin{array}{l}\text { Peak value } \\
\text { (ng/ml) }\end{array}$ & $\begin{array}{l}3.22 \\
(0.69-5.9)\end{array}$ & $\begin{array}{l}2.8 \\
(0.6-5.3)\end{array}$ & 0.21 \\
\hline $\begin{array}{l}\text { Absolute increase } \\
(\mathrm{mg} / \mathrm{dl})\end{array}$ & $\begin{array}{l}61.5 \\
(0-120)\end{array}$ & $\begin{array}{l}46 \\
(0-89)\end{array}$ & 0.1 & $\begin{array}{l}\text { Absolute increase } \\
(\mathrm{ng} / \mathrm{ml})\end{array}$ & $\begin{array}{l}0.99 \\
(0.15-2.5)\end{array}$ & $\begin{array}{l}0.6 \\
(0-2.15)\end{array}$ & 0.08 \\
\hline $\begin{array}{l}\text { Percent increase } \\
\text { (\%) }\end{array}$ & $\begin{array}{l}32.04 \\
(0-50.77)\end{array}$ & $\begin{array}{l}18.6 \\
(0-48.63)\end{array}$ & 0.04 & $\begin{array}{l}\text { Percent increase } \\
\text { (\%) }\end{array}$ & $\begin{array}{l}61.94 \\
(4.47-108.69)\end{array}$ & $\begin{array}{l}28.88 \\
(0-110.25)\end{array}$ & 0.17 \\
\hline $\begin{array}{l}\text { IAUC } \\
\left(\mathrm{mg} \mathrm{dl} \mathrm{I}^{-1} \mathrm{~min}^{-1}\right)\end{array}$ & $\begin{array}{l}4.27 \\
(0-9.15)\end{array}$ & $\begin{array}{l}3.22 \\
(0-6.91)\end{array}$ & 0.18 & $\begin{array}{l}\text { IAUC } \\
\text { (ng ml-1 } \mathrm{min}^{-1} \text { ) }\end{array}$ & $\begin{array}{l}2.47 \\
(0.22-6.2)\end{array}$ & $\begin{array}{l}1.2 \\
(0-3.35)\end{array}$ & 0.07 \\
\hline $\begin{array}{l}\text { TAUC } \\
\left(\mathrm{mg} \mathrm{dl}^{-1} \mathrm{~min}^{-1}\right)\end{array}$ & $\begin{array}{l}3.02 \\
(2.02-3.96)\end{array}$ & $\begin{array}{l}3.29 \\
(1.18-5.97)\end{array}$ & 0.82 & $\begin{array}{l}\text { TAUC } \\
\left(\mathrm{ng} \mathrm{ml}^{-1} \mathrm{~min}^{-1}\right)\end{array}$ & $\begin{array}{l}11.37 \\
(2.24-19.39)\end{array}$ & $\begin{array}{l}9.17 \\
(1.68-18.55)\end{array}$ & 0.12 \\
\hline
\end{tabular}




\section{Discussion}

The combination of SU and bedtime insulin has been indicated in the treatment of secondary failure of oral agents because it can reduce insulin doses and simplify insulin therapy in patients with diabetes type 2 . Nowadays, most of the patients usually start combined therapy earlier than ours did, although the criteria for patient selection for this type of treatment have not been fully established.

The presence of residual insulin secretion, with a minimal basal C-peptide $>1 \mathrm{ng} /$ $\mathrm{ml}$ (9) and/or poststimulus levels $>1.8 \mathrm{ng} / \mathrm{ml}$ (14) have been pointed out as a prerequisite for a good response to combined therapy. According to these parameters, we expected a good response to combined therapy in 22 patients (88\%) since their C-peptide levels prior to insulin use were above these levels. However, only 12 patients $(48 \%)$ were able to maintain their FPG levels below $140 \mathrm{mg} /$ $\mathrm{dl}$ and 8 of them (32\%) normalized them. Despite the heterogeneity of our sample concerning age, duration of diabetes and BMI distribution which could have influenced our results, our data are similar to others (1517). Nevertheless the exact mechanism underlying the non-response to combined therapy in some patients has not been established.

Two of the three patients who had Cpeptide levels below these levels had BMI under $25 \mathrm{~kg} / \mathrm{m}^{2}$ and diabetes duration less than 5 years, but all three were $\geq 35$ years old at the diagnosis of diabetes. One of them responded to combined therapy, and the others had their FPG improved with this therapy. In these patients, the presence of glutamic acid decarboxylase antibody should be investigated in order to exclude latent autoimmune diabetes mellitus in adults (18).

The better metabolic control achieved by our patients with combined therapy was not accompanied by an absolute increment in the beta-cell response to a mixed meal, but we could demonstrate the reversibility of glucose toxicity by the increase in beta-cell sensitivity to the same stimulus, with the improvement in the C-peptide/glucose score. (13).

A decrease in HbA1 after combined therapy was not noted. Probably a longer duration of combined therapy would be necessary to produce a significant decrease in $\operatorname{HbA} 1(9,16,17,19)$. Recently it was demonstrated that there is a great individual difference in time course in changing $\mathrm{HbA} 1 \mathrm{c}$ to its lowest value, with a half-time ranging from 19.5 to 48.7 days (20).

When SU was withdrawn (phase 3), a $50 \%$ increase in insulin dose was observed, as also reported in other studies $(9,11,14$ $17,21,22)$. Despite this increment, only three patients among those who responded to combined therapy maintained their FPG below $140 \mathrm{mg} / \mathrm{dl}$ in phase $3(\mathrm{P}<0.02)$. Certainly, more complex regimens of insulin therapy would be necessary to maintain the same level of control obtained during combined therapy (6).

Although there was a significant reduction in all points of the glycemic curve during phase 2 compared to phases 1 and 3, a more marked decrease in fasting blood levels than in the postprandial points of the glycemic curve was observed. These results demonstrate a greater influence of combined therapy on FPG than on postprandial glucose $(11,15,23)$. This fact may be attributed to the suppression of hepatic production of glucose by NPH insulin given at bedtime $(11,24)$.

A significant weight gain was observed during combined therapy as demonstrated by others $(16,25)$, corresponding to an average of $2 \mathrm{~kg}$. The increment in insulin doses in phase 3 did not cause an additional weight gain. The decrease in the energy lost as glucose in the urine could explain the weight gain during combined therapy. In fact, our patients reported that their urine in the semiquantitative tests for glucose was negative 
during combined therapy, but we did not determine the total glucose lost in 24-h urine collection (24) or dietary intake to support this hypothesis. Studying the causes of weight gain during insulin therapy, some authors demonstrated that the improvement in metabolic control promotes weight gain by decreasing both basal metabolic rate and glucosuria (26).

As also observed in other studies $(17,19)$, duration of disease, BMI and previous control of the disease were not useful in predicting the response to combined therapy. In our study, only age was significantly different between responders and nonresponders to combined therapy. These results support the conclusions reached in review articles $(25,27)$ that no clinical variable can predict the response to combined therapy in individual patients.

Although we demonstrated a good correlation between fasting and stimulated $\mathrm{C}$ peptide, the former value did not differ between responders and nonresponders to combined therapy. Thus, fasting C-peptide, which could be the easiest method to determine residual beta-cell function (28), was unable to predict a good response to combined therapy in our sample.

On the other hand, a tendency to higher stimulated C-peptide values (C-peptide absolute increase and C-peptide IAUC) was observed among responders. Despite the small number of patients studied (32 patients would be necessary to avoid a type 2 statistical error), this fact emphasizes that the functional test may be more useful to predict a good response to combined therapy than fasting C-peptide.

Although the design of our study was not ideal to affirm that combined therapy was most effective, we observed that combined therapy resulted in a better glycemic response to a mixed meal than insulin monotherapy at bedtime, and should be used in the management of patients with diabetes type 2 before starting insulin as monotherapy, despite difficulties in predicting the response.

\section{Acknowledgments}

We would like to thank Maria de Fátima R. Gonçalves, Eliete Leão S. Clemente, Dr. Helena Gazzola, and Dr. Trude Dimetz for laboratory assistance, and Servier from Brazil for the supply of Gliclazide tablets.

\section{References}

1. Krall LP \& Bradley RF (1962). “Secondary failures" in the treatment of diabetes mellitus with tolbutamide and with phenformin. Diabetes, 2 (Suppl): S88-S91.

2. Groop LC, Pelkonen R, Koskimies S, Bottazzo GF \& Doniach D (1986). Secondary failure to treatment with oral antidiabetic agents in NIDDM. Diabetes Care, 9: 129-133.

3. Groop L, Schalin C, Franssila-Kallunki A, Widen E, Ekstrand A \& Eriksson J (1989). Characteristics of NIDDM patients with secondary failure to oral antidiabetic therapy. American J ournal of Medicine, 87: 183-190.

4. Riddle MC (1996). Combined therapy with a sulfonylurea plus evening insulin: Safe, reliable and becoming routine. Hormone and Metabolic Research, 18: 430-433.

5. Wolffenbuttel BHR, Sels J-P, Rondas-
Colbers G, Menheere P \& Kruseman AC (1996). Comparison of different insulin regimens in elderly patients with NIDDM. Diabetes Care, 19: 1326-1332.

6. Yki-J arvinen $\mathrm{H}$, Kauppila $\mathrm{M}$, Kujansuu $\mathrm{E}$, Lahti J , Marjanen T, Niskanen L, Rajala S, Ryysy L, Salo S, Seppälä Ptulokas T, Viikari J , Karjalainnen J \& Taskinem M-J (1992). Comparison of insulin regimens in patients with non-insulin-dependent diabetes mellitus. New England J ournal of Medicine, 327: 1426-1433.

7. Service EJ, Rizza RA, Zimmerman BR, Dycy P, O'Brien P \& Melton III L (1997). The classification of diabetes by clinical and C-peptide criteria. Diabetes Care, 20: 198-201.

8. Castillo M, Scheen AJ, Paolisso G \& Lefevre PJ (1987). The addition of glipizide to insulin therapy in type-II diabetic pa- tients with secondary failure to sulfonylurea is useful only in the presence of a significant residual insulin secretion. Acta Endocrinologica, 116: 364-372.

9. Quartraro A, Consoli G, Ceriello A \& Giugliano D (1986). Combined insulin and sulfonylurea therapy in NIDDM with secondary failure to oral drugs: a one year follow up. Diabetes and Metabolism, 12: 315-318.

10. National Diabetes Data Group (1979). Classification and diagnosis of diabetes mellitus and other categories of glucose intolerance. Diabetes, 28: 1039-1057.

11. Stenman S, Groop P-H, Saloranta C, Totterman KJ , Fyhrqvist F \& Groop L (1988). Effects of the combination insulin and glibenclamide in type 2 diabetic patients with secondary failure to oral hypoglycemic agents. Diabetologia, 31: 206- 
213.

12. Pozzan R, DimetzT, Gazolla HM \& Gomes MB (1997). The C-peptide response to a standard mixed meal in a group of Brazilian type 1 diabetic patients. Brazilian J ournal of Medical and Biological Research, 30: 1169-1174.

13. Osei $K$ (1986). Clinical evaluation of determinants of glycemic control. A new approach using serum glucose, C-peptide, and body mass indexes in type II diabetic patients. Archives of Internal Medicine, 146: 281-285.

14. Ward WK, Bolgiano DC, McKnight B, Halter J \& Porte J r D (1984). Diminished ßcell secretory capacity in patients with NIDDM. J ournal of Clinical Investigation, 74: 1318-1328.

15. Aschner P \& Kattah W (1992). Effects of the combination of insulin and gliclazide compared with insulin alone in type 2 diabetic patients with secondary failure to oral hypoglycemic agents. Diabetes Research and Clinical Practice, 18: 23-30.

16. Groop LC, Widen E, Ekstrand A, Saloranta C, Franssila-Kallunki A, Schalin-J antti C \& Eriksson J (1992). Morning or bedtime $\mathrm{NPH}$ insulin combined with sulfonylurea in treatment of NIDDM. Diabetes Care, 15: 831-834

17. Ravnik-Oblak M \& M revlje F (1995). Insulin versus a combination of insulin and sulfonylurea in the treatment of NIDDM patients with secondary oral failure. Diabetes Research and Clinical Practice, 30: 27-35.

18. Zimmet PZ, Tuomi T, Mackay IR, Rowley MJ, Knowles W, Cohen M \& Lang DA (1994). Latent autoimmune diabetes mellitus in adults (LADA): the role of antibodies to glutamic acid decarboxylase in diagnosis and prediction of insulin dependency. Diabetic Medicine, 11: 299-303.

19. Reaven GM, Fraze E, Chen NY, Hollenbeck C \& Chen YD (1989). The combined use of insulin and sulfonylurea therapy in patients with NIDDM. Hormone and Metabolic Research, 21: 132-136.

20. Tahara $Y \&$ Shima K (1995). Kinetics of $\mathrm{HbAlc}$, glycated albumin and fructosamine and analysis of their weight functions against predicting plasma glucose level. Diabetes Care, 18: 440-447.

21. Gutniak M, Karlander SG \& Efendid S (1987). Glyburide decreases insulin requirement, increases beta-cell response to mixed meal, and does not affect insulin sensitivity: effects of short and long-term combined treatment in secondary failure to sulfonylurea. Diabetes Care, 10: 545554.

22. Soneru IL, Agrawal L, Murphy J C, Lawrence AM \& Abraira C (1993). Comparison of morning or bedtime insulin with and without glyburide in secondary sulfonylurea failure. Diabetes Care, 16: 896901.

23. Simonson DC, Delprato $S$, Castellino $P$, Groop L \& DeFronzo RA (1987). Effect of glyburide on glycemic control, insulin requirement, and glucose metabolism in insulin-treated diabetic patients. Diabetes, 36: 136-146.

24. Shank ML, Del Prato $S \&$ DeFronzo RA (1995). Bedtime insulin/daytime glipizide. Effective therapy for sulfonylurea failures in NIDDM. Diabetes, 44: 165-172.

25. Pugh J A, Wagner ML, Sawyer J , Ramirez G, Tuley M \& Friedberg S (1992). Is combination sulfonylurea and insulin therapy useful in NIDDM patients? Diabetes Care, 15: 953-959.

26. Mäkimattila $S$, Nikkilä $K \&$ Yki-J ärvinen $H$ (1999). Causes of weight gain during insulin therapy with and without metformin in patients with type II diabetes mellitus. Diabetologia, 42: 406-412.

27. Lebovitz HE \& Pasmantier R (1990). Combination insulin-sulfonylurea therapy. Diabetes Care, 13: 667-675.

28. Faber OK \& Binder C (1977). C-peptide response to glucagon. A test for the residual beta-cell function in diabetes mellitus. Diabetes, 26: 605-610. 